\title{
Research Journal of
}

Business and Management

Year: 2015 Volume: 2 Issue: 1

\section{DEMOGRAPHIC DIVERSITY IN THE BOARDROOM: EVIDENCE FROM BORSA ISTANBUL}

DOI: 10.17261/Pressacademia.201519785

Emrah Arioglu'

${ }^{1}$ Cukurova University. earioglu@cu.edu.tr

$\begin{array}{ll}\text { Keywords } & \text { ABSTRACT } \\ \text { Diversity, } & \text { This study investigates demographic diversity in the boards of public firms } \\ \text { gender, } & \text { quoted at Borsa Istanbul. The findings show that female directors are neither } \\ \text { nationality, corporate } & \text { less educated nor less professionally qualified than male directors. However, } \\ \text { governance, } & \text { consistent with the glass ceiling arguments, the percentage of female directors } \\ \text { Borsa Istanbul. } & \text { that are CEOs or chairmen is lower compared to male directors. Also, a lower } \\ & \text { percentage of them are independent and serve on audit committees. The } \\ & \text { findings also show that a lower percentage of foreign directors are independent, } \\ & \text { busy and serve on audit committees compared to Turkish directors. In addition, } \\ & \text { directors that are CEOs, busy directors or independent directors are younger. } \\ & \text { However, chairmen of firms are older. Lastly, the findings show that firms with } \\ \text { foreign directors have lower total advice quality, compared to firms with no } \\ \text { foreign directors. However, firms with female directors do not have a } \\ \text { sEL Classification }\end{array}$

\section{INTRODUCTION}

Numerous studies (Burgess and Tharenous, 2002; Carter et al., 2003; Arfken et al., 2004; Peterson and Philpot, 2007; Anderson et al., 2011; Dobbin and Jung, 2011) investigate the importance of diversity in the directors of boards. These studies argue that increased diversity could potentially promote creativity, efficient problem-solving, a better understanding of the markets by matching the diversity of the markets, improved skill sets, improved company image, increased speed in the decision making process and enhanced effectiveness of corporate leadership. Erhardt et al., 2003 argues that diversity measures can be divided into two groups: (i) observable (demographic) diversity measures such as gender, nationality and age, and (ii) non-observable diversity measures such as education and professional expertise. In this study, I investigate observable diversity in the boards of public firms listed at Borsa Istanbul.

There is no doubt that finance scholars value the terms performance and firm value the most. Thus, the majority of previous work on diversity in public firms quoted at Borsa Istanbul (Ararat et al., 2010; Ocak, 2013; Solakoglu, 2013; and Karayel and Dogan, 2014) focus on the performance implications of demographic diversity with a main focus on gender diversity. Still, the characteristics of directors are important for firms as well, because company performance would depend on company strategies, which depend on 
the characteristics of strategic decision makers in that company (Heijltjes et al., 2003; Van Veen and Marsman, 2008).

Therefore, a detailed investigation of characteristics of directors with various demographic backgrounds could add to our understanding of the potential effects of the existence of these diverse directors on firm performance and value. That is the main goal of this paper.

The first topic I investigate is the existence of female directors on boards. The percentage of female directors on boards has increased in the last decade, especially in the post-SOX period (Bernardi et al., 2006; Dalton and Dalton, 2010). Still, this percentage is substantially low, except in countries such as Norway and Spain (Ferreira, 2010). One of the potential explanations for this is that female directors could be perceived as lacking the necessary qualifications for board appointments (Peterson and Philpot, 2007; Terjesen et al., 2009). However, empirical evidence does not support this explanation (Adams and Flynn, 2005; Dunn, 2012; Virtanen, 2012).

There is no doubt that the addition of female directors to boards could provide the benefits of increased diversity summarized in the first paragraph. In addition, female directors could (i) provide boards with knowledge of female market segmentation and transformational leadership styles (Singh et al., 2008), (ii) serve as role models for lower level female executives (Sealy and Singh, 2010), (iii) help create a female worker friendly environment (Tate and Yang, 2014), and (iv) improve company image and reputation (Burgess and Tharenous, 2002; Brammer et al., 2009). Thus their existence in boards could be expected to be valued highly by financial markets (Bear et al., 2010; Campbell and Vera, 2010; Ntim, 2014). Still, existence of female directors on boards could introduce potential costs as a result of problems such as (i) conflicts and communication problems, (ii) biases against their sound decisions as a result of male directors considering them as out-group members (Shin, 2012), and (iii) the lack of independence of female directors (Ruigrok et al., 2007).

The majority of empirical studies provide evidence suggesting that the existence of female directors have positive effects on various corporate issues such as (i) improved performance and value (Erhardt et al., 2003; Carter et al., 2003; Francoeur et al., 2008; Anderson et al., 2011; Lückerath-Rovers, 2013, Peni, 2014), (ii) increased board meeting attendance, (iii) increased CEO performance-turnover sensitivity (Adams and Ferreira, 2009), and (iv) smaller gender gap in compensation of top executives (Shin, 2012). However, Rose (2007) and Carter et al. (2010) find no relationship between firm performance and representation of female directors on boards. Abdullah (2013), on the other hand, provides evidence suggestive of a negative relationship. In addition, Conyon and Mallin (1997) and Peterson and Philpot (2007) show that female board members are less likely to serve on the committees of boards compared to male directors. Studies investigating the effects of female directors on firm performance for Turkish capital markets provide mixed findings (Ararat et al., 2010; Ocak, 2013; Solakoglu, 2013; Karayel and Dogan, 2014).

Based on these arguments, one could expect the potential benefits of the existence of female directors on boards to outweigh potential costs, and thus, a high percentage of female directors on boards. However, the findings of this study show that only $11 \%$ of 
directors of public firms are female directors. In addition, the percentage of female directors that are CEOs or chairmen is significantly lower compared to the percentage of male directors. This raises the question of why the glass ceiling (Karen and Thompson, 1997) still exists. One could potentially suggest lower qualification as the underlying reason. However, the findings show that female directors are not less educated than male directors.

Also, female directors are not professionally less-qualified than male directors. Still, a lower percentage of them are independent and serve on audit committees. In addition, boards with female directors do not have a lower total advice quality than boards with no female directors.

The next issue I investigate is national diversity. Globalization of markets around the globe has led to internalization of business operations of many firms (Heijltjes et al., 2003), resulting in global partners, foreign institutional shareholders, foreign direct investments, and sales to international markets. This requires firms to have an understanding of dynamics of foreign markets. One way that this could be achieved more effectively is the existence of directors with knowledge and experience in those markets, and advising provided by them (Ramaswamy and Li, 2001; Ruigrok et al., 2006; Van Veen and Marsman, 2008; Greve et al., 2009; Masulis et al., 2012; and Daniel et al., 2013, Morikawa, 2014). In addition, these directors could provide the potential benefits of director heterogeneity discussed so far.

Foreign directors on boards could also (i) bring international experience to the board, (ii) provide boards with valuable external connections such as those to business, social and political circles (Masulis et al., 2012), (iii) signal firms' intentions for globalization (Ramaswamy and Li, 2001), (iv) signal efforts of a company against discrimination (Erhardt et al., 2003), and (v) improve the reputation of firms in the market (Oxelheim and Randoy, 2003). Also, if these foreign directors are tied to foreign shareholders/partners in local firms, their existence could potentially signal more effective monitoring as a result of improved oversight from foreign shareholders (Ararat et al., 2010). In addition, the existence of such directors could have an effect on the decision making process of firms, which would be expected to be reflected to firm performance (Ramaswamy and Li, 2001; Van Veen and Marsman, 2008).

Indeed, there could be potential costs related to the existence of foreign directors on boards such as conflicts and communication problems (Erhardt et al., 2003). In addition, if the director resides abroad, a decrease in effectiveness of monitoring could be expected as a result of (i) difficulties and time constraints in visits to headquarters, (ii) less access to firm-specific information, (iii) decreased ability of the director to cope with issues such as the accounting applications, business applications and regulations of another country, (iv) extra time and energy consumption required for international traveling and time zone differences (Masulis et al., 2012), and (v) potential language barriers (Piekkari et al., 2013).

Masulis et al. (2012) provide evidence suggesting that the existence of foreign directors have negative effects on firm performance. However, Daniel et al. (2013) show that foreign directors have a positive effect on firm value. Oxelheim and Randoy (2003), and Ntim (2013) provide parallel findings. 
Based on these arguments and empirical evidence, one could expect shareholders to elect foreign directors to boards if they believe that the potential benefits associated with their existence would outweigh the costs. Especially firms with global operations and foreign partners could be expected to have a higher percentage of foreign directors on their boards. The results show that around $11 \%$ of directors in the sample are foreigners. Compared to Turkish directors, a lower percentage of foreign directors are independent directors.

Also, a lower percentage of foreign directors are finance experts or lawyers. In addition, a lower percentage of them serve on audit committees of firms. Lastly, firms with foreign directors on their boards have lower total advice quality, compared to firms with no foreign directors on their boards. These patterns could be explained by the behavior of foreign companies that have partnerships with Turkish companies in electing their employees as foreign directors for increased oversight purposes, rather than companies hiring foreign directors with the belief that they would be more effective directors compared to domestic directors. Untabulated results support this argument. The results show that in 2012, the mean foreign director ratio for firms with no foreign blokcholders was $2.84 \%$, whereas it was $36.82 \%$ for firms with at least one foreign blockholder.

The last issue I investigate is age diversity. Directors beyond a certain age have received criticism from the public media, especially following the crisis of 2008 (Berman, 2008). In addition, reform advocates in some developed economies suggest the imposition of mandatory retirement ages for directors and CEOs (Arioglu, 2013). Economics, psychology, and sociology literature provides evidence of the negative effects of age on work performance (Waelchli and Zeller, 2013), which could apply to members of boards, as well.

As they get older, directors (i) could become less effective (Core et al., 1999), (ii) might require stronger explicit incentives as they get closer to retirement age (Gibbons and Murpy, 1992), and (iii) would be expected to use less sophisticated techniques in their decision-making processes, such as those related to the investment strategy of firms, having potential effects on value of the firms (Graham and Harvey, 2001). On the other hand, older directors could provide boards with stability, experience and wisdom (Anderson et al., 2011), and be beneficial in the development of younger directors. However, younger directors might work harder in order to show their worth to the market, as a result of their career concerns. They could also potentially bring more riskaversion and energy to the boardroom (Anderson et al., 2011).

In empirical studies, Wegge et al. (2008), McIntryre et al. (2007) show that age diversity has a positive effect on firm performance. However, Korniotis and Kumar (2011) and Waelchli and Zeller (2013) provide evidence suggesting that director age has negative effects on firm decisions and performance. In terms of initial public offerings and reverse leveraged buyouts, which are associated with "more effective" governance applications by firms, there is evidence suggesting that these firms appoint younger directors and CEOs (Gertner and Kaplan, 1996; Boone et al., 2007; Cornelli and Karakaş, 2012).

Based on these arguments, one could expect chairmen of companies to be older since these positions would require experience and wisdom. On the other hand, remaining 
members of boards and committee members could be expected to be younger based on the argument of Anderson et al. (2011). As expected, directors that are chairmen are significantly older compared to other directors. On the other hand, directors that are CEOs are significantly younger than directors, who are not CEOs. As expected, busy and independent directors are significantly younger.

Before succeeding, it should be noted that previous studies investigating diversity at Borsa Istanbul firms limit their samples to no more than 101 firms that are public.

On the other hand, my sample includes directors on boards of around 290 firms, covering all the firms quoted at the National and Secondary markets of Borsa Istanbul.

\section{DATA}

In this study, I use hand-collected data, which is gathered from annual reports of firms. These are reports that public Turkish companies are required to submit to the Public Disclosure Platform. I also utilized data collected from the official web pages of the companies. I excluded banks that are quoted at Borsa Istanbul. Before 2012, firms were not required to share detailed information regarding their directors with the public. Therefore, I conduct this study on firms that were public by the end of the years 2012 and 2013. This leaves me with a sample of 2079 board members for the end of year 2012, and 2066 board members for the end of year 2013. It should also be noted that the data for some of the variables employed in this study is not available for all the directors. For instance, for some directors, firms do not inform the public regarding professional expertise or age of directors.

In this study, director ownership states the percentage of shares owned by a director alone. The highest level of degree earned by a director is defined by the education level. Abroad education states whether the director has a degree of bachelors or higher earned from an institution, which is not located in Turkey. A finance expert is a director, who has been, or currently is the CEO or on the board of a financial institution. A director is defined as an accounting expert is she certifies as a CPA or equivalent. Professor and Lawyer define the profession of the director if she is in that profession. Membership number states total number of firms, that are not non-profit, whose boards directors sit on. A director is defined as independent if she meets independence requirements imposed by the Principles of Corporate Governance. In addition, a busy director is the one, who is an independent director on focal firm and is on board of at least three different firms that are not non-profits, following Fich and Shivdasani (2006). Various committee membership variables state whether director is on those boards, separately. 
Table 1: Descriptive Statistics for Directors

The sample includes firms quoted at Borsa Istanbul National and Secondary markets at the end of the years 2012 and 2013, with 2079 board members for the end of year 2012, and 2066 board members for the end of year 2013. The education level of a director shows the highest level of degree earned by her. Abroad education states whether she has earned a degree of bachelors or higher from an institution not located in Turkey. A director is defined as a finance expert is she has been, or currently is the CEO or on the board of a financial institution. A director is defined as an accounting expert is she certifies as a CPA or equivalent. Average directorship number states how many non-profit firms' board the directors the director stays on. A director is defined as an independent director if she meets the independence requirements imposed by the Principles of Corporate Governance. A director is defined as a busy director, if she is an independent director on the focal firm and she is on the board of at least three different firms that are not non-profits.

\begin{tabular}{lrr} 
& Director Characteristics & \\
\hline & $\mathbf{2 0 1 2}$ & $\mathbf{2 0 1 3}$ \\
\hline Number of Directors & 2079 & 2066 \\
Female & 238 & 229 \\
Foreigner & 226 & 237 \\
PhD Degree & 181 & 186 \\
Masters Degree & 567 & 543 \\
College Degree & 1006 & 1016 \\
High School or Lower & 92 & 86 \\
Abroad Education & 778 & 753 \\
Finance Expert & 745 & 769 \\
Accounting Expert & 210 & 213 \\
Lawyer & 126 & 111 \\
Professor & 119 & 119 \\
Audit Committee Member & 551 & 559 \\
Governance Committee Member & 628 & 664 \\
Risk Committee Member & 236 & 487 \\
Average Directorship Number & 3.32 & 3.45 \\
Age & 54.33 & 54.71 \\
Independent Director & 607 & 613 \\
Busy Director & 171 & 195 \\
\hline
\end{tabular}

To calculate the proxy for the advising quality of boards, I follow Coles et al. (2014). I determine which other firms' boards the independent director stays and count number of directors on those firms' boards (excluding her). Then, I calculate total number of outside board connections for independent board members on a specific board, eliminating duplicate ties for board members. This sum is called "total advising". In addition, I consider external connections only in other public firms, since data is not available for non-public firms. For example if director Abc Xyz stays on the board of $T$ Corp. as an 
external connection, and T Corp. is not a public company, I am not able to find the other directors in that company, whom Abc Xyz is connected to.

The descriptive statistics regarding the sample are presented in Table 1. The Table shows that around $11 \%$ of the directors on company boards are females. $11 \%$ of directors are foreigners. It can also be observed that over $95 \%$ of the directors have degrees earned at least at bachelor level. A good portion of these directors are finance experts. However, same cannot be stated in terms of being accounting experts, lawyers, or professors. These directors hold, on average around 3.40 board seats in for-profit firms. The average director age is approximately 54. Out of these directors, almost $30 \%$ are independent. In addition, approximately $9 \%$ of them are busy.

\section{RESULTS}

\subsection{Gender}

Findings regarding female directors are presented in Table 2. The Table shows that around $11 \%$ of directors in public firm boards are females. The percentages of female directors that are CEOs or chairmen in firms are significantly lower compared to male directors. In $2013,3.49 \%$ of female directors are CEOs, whereas $7.68 \%$ of male directors are CEOs. Out of these 229 female directors, $7.11 \%$ are chairmen. On the other hand $14.62 \%$ of male directors are chairmen. Even though female directors do not appear to be significantly less educated or less of experts as shown in Table 2, they still hold less leadership positions in firms. These findings could potentially be explained by the glass ceiling, which is suggested to prevent female from being promoted to top positions in teams, such as boards (Karen and Thompson, 1997).

On the other hand, around $20 \%$ of female directors are independent, which is significantly lower compared to male directors. This evidence is consistent with the arguments of Ruigrok et al. (2007), even though it contradicts the findings of Conyon and Mallin (1997). One potential explanation could be that, as Ruigrok et al. (2007) argue, these directors are appointed to boards based on recommendations of CEOs or chairmen of boards, who run family controlled firms and these female directors are members of families, and are not independent.

Table 2 also presents that 3.93\% of these female directors are foreigners. However, a significantly higher percentage of male directors are foreigners, $12.41 \%$. This could be explained by the fact that even in other countries, percentage of female directors are significantly lower in boardrooms and therefore, in the case that these foreign directors are appointed to boards as a result of partnerships with or ownership by foreign companies, it is natural that their existence in boards are lower.

In terms of education qualifications of these female directors, $3.09 \%$ have $\mathrm{PhD}, 31.44 \%$ have masters, and $58.24 \%$ have bachelor degrees. These figures point out to the fact that female directors are not under-educated, compared to male directors. The opposite could have been expected to be observed maybe couple decades ago. In terms of higher education degrees earned from institutions that are not located in Turkey, around $41 \%$ of directors have these degrees, which is almost the same for male directors. 
In terms of age, what is observed is that female directors are significantly younger. On average, they are 48.74 years old, whereas male directors are 55.38 years old. A potential explanation for this would be that in earlier decades, females' school attendance and employment rates were lower and thus majority of the older directors are male directors. This is in accordance with the figures presented in Table 4.

On the other hand, in terms of professional expertise, what is observed is that $46.63 \%$ of female directors are finance experts. $7.32 \%$ of them are accounting experts, $5.16 \%$ of them are lawyers, and $3.29 \%$ of them are professors. These findings suggest that, in terms of professional qualification, female directors are not significantly less qualified than male directors. Thus, a potential argument suggesting that the percentage of female directors on boards being low is an outcome of their lower qualifications (Peterson and Philpot, 2007; Terjesen et al., 2009) does not appear to be valid.

Another figure presented in Table 2 is the existence of female directors on important board committees. Table 2 shows that $18.75 \%$ of female directors are appointed to auditing committees, which is significantly lower compared to male directors. One could argue that this is an outcome of their lower qualifications. However, the findings so far do not support this view. An alternative explanation could be the fact that a lower percentage of female directors are independent directors and PCG requires audit committees to be composed of solely independent directors. If the qualification argument was to be valid, then a similar pattern could have been observed in terms of appointments to other board committees. However, it is not. $30.80 \%$ of female directors serve on governance committees, whereas $20.54 \%$ of them serve on risk committees. These figures are not significantly lower, compared to male directors.

In terms of total board membership numbers, female directors, on average, stay on boards of 3.30 for-profit firms' boards. This figure is 3.47 board seats for male directors. This evidence could be considered to suggest that female directors are assigned to board seats as often as male directors. However, it contradicts the main finding of low female presentation on boards. A potential explanation could be that these female directors stay on boards of firms that are controlled by a group or family, and female directors receive board appointments on these non-public firms' boards as a result of their ties with the group or family. In terms of the percentage of female directors that are busy, the figure is $7.25 \%$. This percentage is not significantly different compared to male directors. Also, female directors are not different than male directors in terms of average share ownership. 


\section{Table 2: Gender Diversity}

The sample includes firms quoted at Borsa Istanbul National and Secondary markets at the end of the years 2012 and 2013, with 2079 board members for the end of year 2012, and 2066 board members for the end of year 2013. The education level of a director shows the highest level of degree earned by her. Abroad education states whether she has earned a degree of bachelors or higher from an institution not located in Turkey. A director is defined as a finance expert is she has been, or currently is the CEO or on the board of a financial institution. A director is defined as an accounting expert is she certifies as a CPA or equivalent. Average directorship number states how many non-profit firms' board the directors the director stays on. A director is defined as an independent director if she meets the independence requirements imposed by the Principles of Corporate Governance. A director is defined as a busy director, if she is an independent director on the focal firm and she is on the board of at least three different firms that are not non-profits. Total advising quality is calculated following Coles et al. (2014).

\begin{tabular}{|c|c|c|c|c|}
\hline & \multicolumn{2}{|c|}{2012} & \multicolumn{2}{|c|}{2013} \\
\hline & \multicolumn{4}{|c|}{ PANEL A: Means and Percentages of Directors } \\
\hline & Female & Male & Female & Male \\
\hline Number of Directors & 238 & 1841 & 229 & 1837 \\
\hline CEO & $* * * 3.36 \%$ & $7.82 \%$ & $* * * 3.49 \%$ & $7.68 \%$ \\
\hline Chairman & $* * * 7.26 \%$ & $14.87 \%$ & $* * * 7.11 \%$ & $14.62 \%$ \\
\hline Independent & $* * * 20.17 \%$ & $30.51 \%$ & $* * * 19.21 \%$ & $30.97 \%$ \\
\hline Foreigner & $* * * 2.52 \%$ & $11.95 \%$ & $* * * 3.93 \%$ & $12.41 \%$ \\
\hline PhD Degree & $3.90 \%$ & $10.54 \%$ & $3.09 \%$ & $10.99 \%$ \\
\hline Masters Degree & $34.14 \%$ & $30.28 \%$ & $31.44 \%$ & $29.44 \%$ \\
\hline College Degree & $54.14 \%$ & $54.40 \%$ & $58.24 \%$ & $55.16 \%$ \\
\hline High School or Lower & $7.80 \%$ & $4.78 \%$ & $7.23 \%$ & $4.41 \%$ \\
\hline Abroad Education & $41.95 \%$ & $42.32 \%$ & $41.24 \%$ & $41.26 \%$ \\
\hline Age & $* * * 47.70$ & 55.11 & $* * * 48.74$ & 55.38 \\
\hline Finance Expert & $* 44.50 \%$ & $38.57 \%$ & $* 46.63 \%$ & $40.34 \%$ \\
\hline Accounting Expert & $* * 6.02 \%$ & $11.80 \%$ & $* 7.32 \%$ & $11.92 \%$ \\
\hline Lawyer & $6.14 \%$ & $6.43 \%$ & $5.16 \%$ & $5.80 \%$ \\
\hline Professor & $* 2.63 \%$ & $6.49 \%$ & $* 3.29 \%$ & $6.50 \%$ \\
\hline Audit Committee Member & $* * * 18.14 \%$ & $29.13 \%$ & $* * * 18.75 \%$ & $28.79 \%$ \\
\hline Governance Committee Member & $29.33 \%$ & $32.13 \%$ & $30.80 \%$ & $33.13 \%$ \\
\hline Risk Committee Member & $15.11 \%$ & $11.57 \%$ & $20.54 \%$ & $24.55 \%$ \\
\hline Average Membership \# & 3.31 & 3.32 & 3.30 & 3.47 \\
\hline Busy Director & $* 5.77 \%$ & $9.70 \%$ & $* 7.25 \%$ & $10.73 \%$ \\
\hline \multirow[t]{3}{*}{ Average Share Ownership } & $1.82 \%$ & $2.04 \%$ & $1.59 \%$ & $2.16 \%$ \\
\hline & \multicolumn{4}{|c|}{$\begin{array}{l}\text { PANEL B: The Existence of Female Directors on } \\
\text { Boards }\end{array}$} \\
\hline & No & Yes & No & Yes \\
\hline Total Advice Quality & $* 4.42$ & 6.14 & 4.05 & 5.61 \\
\hline
\end{tabular}

$* * *, * *$, and $*$ present significance at $1 \%, 5 \%$, and $10 \%$ levels.

A very important observation is derived from Panel B of Table 2. The Table shows that in terms of total advice quality, boards that have female directors do not significantly differ from boards with no female directors. The mean total advice quality measure has a value of 4.05 for firms with female directors, whereas this figure is 5.61 for firms with no female directors. I observe similar patterns for 2012. 


\subsection{Nationality}

Table 3 presents findings regarding foreign directors. Around $11 \%$ of directors in the sample are foreigners. Among these foreign directors, $4.64 \%$ are CEOs in firms, whereas $10.55 \%$ are chairmen, at the end of 2013 . These figures reveal that the percentage of foreign directors with top hierarchical positions is not significantly less, compared to nonforeigner directors. This suggests that a modified version of a glass ceiling does not exist for foreign directors. In addition, this could be an outcome of substantial share ownership in public firms by foreign companies and foreign partners of controlling groups electing directors tied to them. The potential ties, which could violate independence, to these foreign companies could also explain the observation that a significantly less percentage of foreign directors are independent directors.

In terms of educational background, Table 3 shows that $10.48 \%$ of these foreign directors have $\mathrm{PhD}$ degrees, whereas $30.00 \%$ have masters and $55.70 \%$ have bachelor degrees. Based on these observations, it can be argued that foreign directors are not lower, or as one could potentially expect, higher educated than domestic directors. However, a potential argument about the quality of the degrees earned could be made, since a very significantly higher percentage of these directors have degrees earned from institutions located outside of Turkey, $98.48 \%$. This figure is not surprising but it is still important, since the common view in Turkey is that education abroad is of higher quality. Rankings of higher education institutions around the globe are supportive of this argument.

Regarding their professional expertise, a significantly lower percentage of foreign directors are finance experts, compared to domestic directors, 32.83\%. However, they do not differ from domestic directors, in terms of the percentages of them that are accounting experts and lawyers. Yet, the percentage of them that are professors is significantly lower, $1.90 \%$. This could potentially be explained by an argument that as a nature of their occupation, professors that are board members at the same time locate in their domestic countries. Thus they are not very highly likely to receive board directorships in Turkey, unless they are retired.

It can also be observed in Table 3 that a significantly lower percentage of foreign directors are on audit committees of firms, $11.16 \%$. This figure is $29.83 \%$ for domestic directors. This could be explained by the argument of Masulis et al. (2012). It is possible that these directors are not familiar with the local accounting applications and regulations, which would be an important factor especially for audit committee membership, as opposed to other committees. The figures are supportive. The percentage of foreign directors that serve on governance committees is $27.90 \%$, while $24.03 \%$ of them serve on risk committees. These figures are not significantly different compared to domestic directors. The average directorship in for-profit firms and the percentage of busy directors among foreign directors is significantly lower compared to domestic directors; 2.92 directorship on average. However, I believe that these figures do not necessarily imply that foreign directors are less busy. It is possible firms at Borsa Istanbul do not disclose information about all current board memberships of these directors, in other countries. 
Alternatively, it is possible that, as an outcome of their ties with foreign controlling groups or partners, these directors locate to Turkey and mainly focus on the operations of focal firms, and quit their board positions in home countries.

Table 3: National Diversity

The sample includes firms quoted at Borsa Istanbul National and Secondary markets at the end of the years 2012 and 2013, with 2079 board members for the end of year 2012, and 2066 board members for the end of year 2013. The education level of a director shows the highest level of degree earned by her. Abroad education states whether she has earned a degree of bachelors or higher from an institution not located in Turkey. A director is defined as a finance expert is she has been, or currently is the CEO or on the board of a financial institution. A director is defined as an accounting expert is she certifies as a CPA or equivalent. Average directorship number states how many non-profit firms' board the directors the director stays on. A director is defined as an independent director if she meets the independence requirements imposed by the Principles of Corporate Governance. A director is defined as a busy director, if she is an independent director on the focal firm and she is on the board of at least three different firms that are not non-profits. Total advising quality is calculated following Coles et al. (2014).

\begin{tabular}{|c|c|c|c|c|}
\hline & \multicolumn{2}{|c|}{2012} & \multicolumn{2}{|c|}{2013} \\
\hline & \multicolumn{4}{|c|}{ PANEL A: Means and Percentages of Directors } \\
\hline & & Not & & Not \\
\hline & Foreigner & Foreigner & Foreigner & Foreigner \\
\hline Number of Directors & 226 & 1853 & 237 & 1829 \\
\hline CEO & $5.75 \%$ & $7.50 \%$ & $* 4.64 \%$ & $7.55 \%$ \\
\hline Chairman & $10.62 \%$ & $14.42 \%$ & $10.55 \%$ & $14.22 \%$ \\
\hline Independent & $* * * 15.04 \%$ & $31.07 \%$ & $* * * 12.66 \%$ & $31.88 \%$ \\
\hline Female & $* * * 2.65 \%$ & $12.52 \%$ & $* * * 3.80 \%$ & $12.03 \%$ \\
\hline Male & $* * * 97.35 \%$ & $87.48 \%$ & $* * * 96.20 \%$ & $87.97 \%$ \\
\hline PhD Degree & $10.50 \%$ & $9.71 \%$ & $10.48 \%$ & $10.04 \%$ \\
\hline Masters Degree & $33.00 \%$ & $30.41 \%$ & $30.00 \%$ & $29.57 \%$ \\
\hline College Degree & $55.50 \%$ & $54.34 \%$ & $55.70 \%$ & $55.23 \%$ \\
\hline High School or Lower & $1.00 \%$ & $5.55 \%$ & $3.82 \%$ & $5.16 \%$ \\
\hline Abroad Education & $* * * 98.49 \%$ & $35.47 \%$ & $* * * 98.48 \%$ & $34.30 \%$ \\
\hline Age & $* * 52.35$ & 54.55 & 53.55 & 54.83 \\
\hline Finance Expert & $34.00 \%$ & $39.87 \%$ & $* * 32.83 \%$ & $42.00 \%$ \\
\hline Accounting Expert & $* 7.50 \%$ & $11.57 \%$ & $9.60 \%$ & $11.63 \%$ \\
\hline Lawyer & $8.96 \%$ & $6.09 \%$ & $8.10 \%$ & $5.45 \%$ \\
\hline Professor & $* * * 1.89 \%$ & $6.55 \%$ & $* * * 1.90 \%$ & $6.67 \%$ \\
\hline Audit Committee Member & $* * * 12.96 \%$ & $29.70 \%$ & $* * * 11.16 \%$ & $29.83 \%$ \\
\hline Governance Committee Member & $* 26.89 \%$ & $32.46 \%$ & $* 27.90 \%$ & $33.52 \%$ \\
\hline Risk Committee Member & $* 16.04 \%$ & $11.48 \%$ & $24.03 \%$ & $24.12 \%$ \\
\hline Average Membership \# & 3.11 & 3.35 & $* * 2.92$ & 3.52 \\
\hline Busy Director & $* * 6.44 \%$ & $9.60 \%$ & $* * * 5.78 \%$ & $10.96 \%$ \\
\hline Average Share Ownership & $* * * 0.04 \%$ & $2.22 \%$ & $* * * 0.04 \%$ & $2.32 \%$ \\
\hline
\end{tabular}

\begin{tabular}{lrrrr} 
Average Share Ownership & $* * * 0.04 \%$ & $2.22 \%$ & $* * * 0.04 \%$ & $2.32 \%$ \\
\hline & \multicolumn{3}{l}{ PANEL B: The Existence of Foreign Directors on } \\
& Boards & & & \\
\hline \multirow{2}{*}{ Total Advice Quality } & No & Yes & No & Yes \\
\cline { 2 - 6 } & $* * 4.75$ & 7.25 & $* * * 3.76$ & 8.15 \\
\hline
\end{tabular}

$* * *, * *$, and $*$ present significance at $1 \%, 5 \%$, and $10 \%$ levels. 
In terms of share ownership in firms, foreign directors own a significantly lower percentage compared to domestic directors, $0.04 \%$. This could be an outcome of them not being tied to families that control firms, which would be the case for domestic directors. In addition, it can be observed in Panel B that firms with foreign directors have lower total advice quality compared to firms with no foreign directors; with values of 3.76 and 8.15 consecutively. This could be, however, an outcome of the observation that a lower percentage of foreign directors are independent, which has a direct effect on the advising quality metric employed. I observe similar patterns for 2012.

\subsection{Age}

The findings regarding the age diversity are presented in Table 4 and Table 5. Table 4 presents the percentages of directors in certain age brackets, with various characteristics. The brackets in the Table are constructed based on the $25 \%, 50 \%$ and $75 \%$ percentiles of age distributions of directors in the specific years. Table 5 presents the comparison of average age values between various groups, such as directors who are CEOs and who are not.

What Table 4 shows is that at the end of 2013, a lower percentage of directors in the oldest directors group are CEOs in the companies, $3.27 \%$. This could potentially be a result of expectations of lower dynamism from older directors, assuming that CEOs would be expected to be more active. In terms of chairmen of boards, the Table shows that a lower percentage of directors in the youngest directors group are chairmen of the firms, compared to other age groups. This could be an outcome of a belief that these younger directors would lack the wisdom and experience required for the chairman position. Another explanation would be that, since majority of the firms quoted at Borsa Istanbul are controlled firms (Arioglu, 2014), the eldest of the controlling family remains as the chairman of the firm.

An interesting pattern observed in Table 4 is that as the age bracket of directors increases, the percentage of them that are independent increases. It could be possible that these directors are appointed as independent directors as they get older and build reputations as effective monitors. Another explanation could be that with their experience, older directors are believed to be more effective monitors, the reason why independent directors are appointed. These could also be the underlying reasons for the observation that as the age bracket gets higher, a higher percentage of directors serve on audit committees, as well. Another interesting pattern is observed for the percentage of directors that are females in an age brackets. As the age bracket gets higher, the percentage of female directors gets lower. This could be an outcome of the fact that, in the earlier decades, females were not very likely to join work force in Turkey, and thus the percentage of female directors that are old is low. 


\section{Table 4: Age Diversity}

The sample includes firms quoted at Borsa Istanbul National and Secondary markets at the end of the years 2012 and 2013, with 2079 board members for the end of year 2012, and 2066 board members for the end of year 2013. The education level of a director shows the highest level of degree earned by her. Abroad education states whether she has earned a degree of bachelors or higher from an institution not located in Turkey. A director is defined as a finance expert is she has been, or currently is the CEO or on the board of a financial institution. A director is defined as an accounting expert is she certifies as a CPA or equivalent. Average directorship number states how many non-profit firms' board the directors the director stays on. A director is defined as an independent director if she meets the independence requirements imposed by the Principles of Corporate Governance. A director is defined as a busy director, if she is an independent director on the focal firm and she is on the board of at least three different firms that are not non-profits. Total advising quality is calculated following Coles et al. (2014).

\begin{tabular}{|c|c|c|c|c|c|c|c|c|}
\hline & \multicolumn{4}{|c|}{$\begin{array}{c}2012 \\
\text { Age Groups }\end{array}$} & \multicolumn{4}{|c|}{$\begin{array}{c}2013 \\
\text { Age Groups }\end{array}$} \\
\hline & $22-47$ & $48-54$ & $55-62$ & $63-91$ & $23-47$ & $48-54$ & $55-62$ & $63-92$ \\
\hline Number of Directors & 836 & 417 & 429 & 397 & 838 & 404 & 426 & 398 \\
\hline CEO & $8.01 \%$ & $8.63 \%$ & $8.39 \%$ & $3.27 \%$ & $7.52 \%$ & $9.16 \%$ & $8.22 \%$ & $3.52 \%$ \\
\hline Chairman & $8.56 \%$ & $17.75 \%$ & $16.71 \%$ & $18.39 \%$ & $8.41 \%$ & $17.33 \%$ & $16.20 \%$ & $18.78 \%$ \\
\hline Independent & $24.85 \%$ & $22.65 \%$ & $34.35 \%$ & $40.30 \%$ & $25.78 \%$ & $23.02 \%$ & $34.51 \%$ & $39.45 \%$ \\
\hline Female & $17.22 \%$ & $11.27 \%$ & $7.69 \%$ & $3.53 \%$ & $15.87 \%$ & $12.87 \%$ & $6.81 \%$ & $3.77 \%$ \\
\hline Male & $82.78 \%$ & $88.73 \%$ & $92.31 \%$ & $96.47 \%$ & $84.13 \%$ & $87.13 \%$ & $93.19 \%$ & $96.23 \%$ \\
\hline Foreigner & $13.64 \%$ & $11.51 \%$ & $8.39 \%$ & $7.05 \%$ & $14.44 \%$ & $12.62 \%$ & $9.15 \%$ & $6.53 \%$ \\
\hline PhD Degree & $7.89 \%$ & $10.73 \%$ & $10.09 \%$ & $11.59 \%$ & $8.25 \%$ & $11.00 \%$ & $8.85 \%$ & $13.60 \%$ \\
\hline Masters Degree & $35.58 \%$ & $30.48 \%$ & $28.51 \%$ & $25.19 \%$ & $34.62 \%$ & $25.75 \%$ & $31.33 \%$ & $23.90 \%$ \\
\hline College Degree & $51.52 \%$ & $55.12 \%$ & $56.71 \%$ & $54.91 \%$ & $52.91 \%$ & $58.50 \%$ & $56.93 \%$ & $54.60 \%$ \\
\hline High School or Lower & $5.01 \%$ & $3.67 \%$ & $4.69 \%$ & $8.06 \%$ & $4.21 \%$ & $4.75 \%$ & $2.88 \%$ & $7.90 \%$ \\
\hline Abroad Education & $45.69 \%$ & $45.37 \%$ & $33.49 \%$ & $43.22 \%$ & $43.95 \%$ & $43.00 \%$ & $35.89 \%$ & $41.01 \%$ \\
\hline Age & 40.62 & 50.95 & 58.28 & 69.98 & 40.57 & 51.04 & 58.36 & 70.18 \\
\hline Finance Expert & $38.20 \%$ & $46.47 \%$ & $35.60 \%$ & $37.47 \%$ & $40.95 \%$ & $48.76 \%$ & $38.21 \%$ & $36.36 \%$ \\
\hline Accounting Expert & $8.91 \%$ & $10.22 \%$ & $12.88 \%$ & $13.80 \%$ & $9.80 \%$ & $11.44 \%$ & $12.26 \%$ & $13.10 \%$ \\
\hline Lawyer & $7.64 \%$ & $4.61 \%$ & $3.97 \%$ & $8.56 \%$ & $6.90 \%$ & $3.97 \%$ & $2.35 \%$ & $9.05 \%$ \\
\hline Professor & $4.23 \%$ & $5.83 \%$ & $6.31 \%$ & $9.32 \%$ & $5.08 \%$ & $5.21 \%$ & $5.88 \%$ & $9.30 \%$ \\
\hline $\begin{array}{l}\text { Audit Committee Member } \\
\text { Governance Committee }\end{array}$ & $24.16 \%$ & $22.33 \%$ & $32.05 \%$ & $36.75 \%$ & $23.49 \%$ & $23.37 \%$ & $31.50 \%$ & $36.55 \%$ \\
\hline Member & $31.74 \%$ & $30.67 \%$ & $34.06 \%$ & $30.97 \%$ & $31.77 \%$ & $33.42 \%$ & $34.37 \%$ & $32.99 \%$ \\
\hline $\begin{array}{l}\text { Risk Committee Member } \\
\text { Average Membership }\end{array}$ & $11.48 \%$ & $9.73 \%$ & $12.56 \%$ & $14.70 \%$ & $22.87 \%$ & $23.62 \%$ & $26.25 \%$ & $24.87 \%$ \\
\hline Number & 3.01 & 3.64 & 3.39 & 3.54 & 3.02 & 3.78 & 3.85 & 3.53 \\
\hline Busy Director & $4.35 \%$ & $11.29 \%$ & $11.79 \%$ & $14.01 \%$ & $6.11 \%$ & $9.11 \%$ & $17.20 \%$ & $12.57 \%$ \\
\hline Average Share Ownership & $1.93 \%$ & $1.91 \%$ & $1.84 \%$ & $2.48 \%$ & $1.83 \%$ & $2.32 \%$ & $1.65 \%$ & $2.93 \%$ \\
\hline
\end{tabular}




\section{Table 5: Mean Age Values for Comparison Groups}

The sample includes firms quoted at Borsa Istanbul National and Secondary markets at the end of the years 2012 and 2013, with 2079 board members for the end of year 2012, and 2066 board members for the end of year 2013. The education level of a director shows the highest level of degree earned by her. Abroad education states whether she has earned a degree of bachelors or higher from an institution not located in Turkey. A director is defined as a finance expert is she has been, or currently is the CEO or on the board of a financial institution. A director is defined as an accounting expert is she certifies as a CPA or equivalent. Average directorship number states how many non-profit firms' board the directors the director stays on. A director is defined as an independent director if she meets the independence requirements imposed by the Principles of Corporate Governance. A director is defined as a busy director, if she is an independent director on the focal firm and she is on the board of at least three different firms that are not non-profits. Total advising quality is calculated following Coles et al. (2014).

\begin{tabular}{lrr}
\hline & $\mathbf{2 0 1 2}$ & $\mathbf{2 0 1 3}$ \\
\cline { 2 - 3 } CEO & Mean Age & Mean Age \\
\cline { 2 - 3 } Not CEO & $* * * 51.73$ & $* * * 51.88$ \\
Chairman & 54.54 & 54.93 \\
Not Chairman & $* * * 57.08$ & $* * * 57.58$ \\
Busy & 53.83 & 54.19 \\
Not Busy & $* * * 57.71$ & $* * * 57.29$ \\
Independent & 53.89 & 54.21 \\
Not Independent & $* * * 56.64$ & $* * * 56.67$ \\
Female & 53.36 & 53.83 \\
Male & $* * * 47.70$ & $* * * 48.74$ \\
Foreigner & 55.11 & 55.38 \\
Not Foreigner & $* * 52.35$ & 53.55 \\
Audit Committee Member & 54.55 & 54.83 \\
Not Audit Committee Member & $* * * 56.42$ & $* * * 56.70$ \\
Governance Committee Member & 53.55 & 53.98 \\
Not Governance Committee Member & 54.41 & 54.83 \\
Risk Committee Member & 54.34 & 54.73 \\
Not Risk Committee Member & 55.02 & 54.61 \\
$* * * * *$ and $*$ present significance at $1 \%, 5 \%$, and $10 \%$ levels. & & 54.82 \\
\hline
\end{tabular}

An interesting pattern is also observed regarding the percentage of foreign directors in each age bracket. As the age Bracket gets higher, the percentage of directors that are foreigners in that age bracket decreases. This could be consequent of a preference by older foreign directors not to be on a board in a foreign country after a certain age, or their willingness to locate back to their home countries after a certain age. An opposite pattern is observed for academicians in each age group. As the age bracket gets higher, the percentage of professors in that group increases. It could be possible that academicians prefer not to be on boards of firms in early stages of their careers. Another reason might be that academicians build their reputations as they get older and have more research and expertise on specific topics and thus are appointed by firms to boards. They could also be preferring to delay any potential board directorships until they retire and still want to be in the business environment. These patterns are observed for both the end of 2012 and 2013. 
The figures in Table 5 are supportive of the evidence in Table 4, and the discussions above regarding the observations about Table 4 . At the end of 2013, directors that are CEOs are significantly younger than directors, who are not CEOs. For the CEO group, the mean age value is $\mathbf{5 1 . 8 8}$, whereas it is $\mathbf{5 4 . 9 3}$ for the other group, at the end of $\mathbf{2 0 1 3}$. However, for chairmen, the opposite is observed. Directors that are chairmen are significantly older, compared to other directors, with an average age of 57.58, as opposed to 54.19. On the other hand, busy directors and independent directors are significantly younger, compared to non-busy and non-independent directors. For busy directors, the mean age value is 57.38, whereas this value is $\mathbf{5 6 . 6 7}$ for independent directors. Lastly, the mean age value for directors, who are on audit committees, is 56.70, significantly higher than directors that are not on these boards. I observe similar patterns for the end of 2012.

\section{CONCLUSIONS}

In this study, I investigate demographic diversity of directors on boards of firms quoted at Borsa Istanbul. Demographic attributes such as gender, age and nationality of directors have attracted substantial attention in corporate governance literature. These demographic characteristics of directors on boards are believed to provide the boardroom with diversity, which is argued to have various benefits for boards and the way their members think and perform.

My findings show that female presentation on boards is low. In addition, the percentages of female directors that are CEOs or chairmen in the firms are significantly lower compared to the percentages of male directors. They are neither less educated nor less professionally qualified than male directors. These findings are supportive of the arguments regarding the existence of a potential glass ceiling. My findings also reveal that a lower percentage of female directors are independent. A lower percentage of female directors serve on audit committees, whereas there is no significance difference, compared to male directors, in terms of the percentage of female directors serving on governance and risk committees.

Based on these findings, one could suggest that public firms could appoint more female directors to boards in order to benefit from potential diversity effects they would have, especially knowing that they are not less educated or professionally qualified compared to male directors. Future research can more formally and in a causal matter investigate the underlying reasons for these observations regarding female directors. In addition, market reaction to appointments of or departures from boards of female directors could be investigated to understand how markets perceive female directors' existence on boards.

Regarding foreign directors, a low percentage of directors on boards of firms quoted at Borsa Istanbul are foreigners. A less percentage of foreign directors are independent directors. Naturally, majority of them have degrees earned from institutions located outside of Turkey. Also, a lower percentage of foreign directors are finance experts or lawyers, and serve on audit committees of firms, with lower share ownership in firms. The average directorship in for-profit firms and the percentage of busy directors among foreign directors is lower compared to domestic directors. In addition, firms with foreign directors on boards have lower total advice quality, compared to firms with no foreign directors on boards. 
Based on these findings, one could suggest that public firms could increase the percentage of foreign directors, especially if they or are planning to have operations in other countries, in order to benefit from positive aspects of diversification. However, it might not be possible to attract foreign directors to move to Turkey for a aboard membership. And in the case that they accept to be board members in Turkish public firms and prefer to reside abroad, potential costs of national diversity in the boardroom could be pronounced. In future studies researchers can investigate the business operations of Turkish firms in other countries and their likelihood of appointing directors from those countries to the boards. Based on the arguments by proponents and opponents of the effectiveness of foreign directors on monitoring, researchers can investigate the relationship between the existence of foreign directors and the likelihood of instances such as fraud or financial restatements.

I also investigate age diversity in public firms and show that directors that are CEOs are younger than directors, who are not CEOs. An opposite pattern is observed in terms of chairmen and their age. Directors that are chairmen are older. In addition, busy directors and independent directors are younger. Lastly, the mean age value for directors on audit committees is lower than directors that are not on these committees. In future studies, researchers can examine the reaction of the market when directors or chairmen announce their retirement as a result of age. Lastly, the preference for older chairmen by firms could be investigated through the examination of the potential founder positions of these chairmen.

Overall, I believe that as the era of corporate governance research is starting for Turkish capital markets, as a consequence of increased accessibility of detailed information following the new Turkish Commercial Code and the Principles of Corporate Governance, there is much to be investigated regarding diversity in the boardroom.

\section{REFERENCES}

Abdullah, S. N. (2013). The Causes of Gender Diversity in Malaysian Large Firms. Journal of Management \& Governance. ISSN 1385-3457.

Adams, S. M., Flynn, P. M. (2005). Local Knowledge Advances Women's Access to Corporate Boards". Corporate Governance: An International Review 13(6), pp. 836-846.

Adams, R. B., Ferreira, D. (2009). Women in the Boardroom and Their Impact on Governance and Performance. Journal of Financial Economics 94(2), pp. 291-309.

Anderson, R. C., Reeb, D. M., Upadhyay, A., Zhao, W. (2011). The Economics of Director Heterogeneity. Financial Management 40(1), pp. 5-38.

Ararat, M., Aksu, M., Cetin, A. T. (2010). Impact of Board Diversity on Boards' Monitoring Intensity and Firm Performance: Evidence from the Istanbul Stock Exchange. Working Paper (Abstract available at: http://ssrn.com/abstract=1572283).

Arioglu, E. (2013). Essays on Reverse Leveraged Buyouts. Drexel University Unpublished PhD Thesis.

Arioglu, E. (2014). A Different Perspective on Ownership at Borsa Istanbul. Working Paper (Abstract available at: http://ssrn.com/abstract=2458121).

Arfken, D., Bellar, S. L., Helms, M. M. (2004). The Ultimate Glass Ceiling Revisited: The Presence of Women on Corporate Boards. Journal of Business Ethics 50, pp. 177-186. 
Bear, S., Rahman, N., Post, C. (2010). The Impact of Board Diversity and Gender Composition on Corporate Social Responsibility and Firm Reputation. Journal of Business Ethics 97, pp. 207-221.

Berman, D. K., 15.09.2008. Where was Lehman's Board?. Retrieved from (http://blogs.wsj.com/deals/2008/09/15/where-was-lehmans-board/)

Bernardi, R. A., Bosco, S. M., Vassill, K. M. (2006). Does Female Representation on Board of Directors Associate with Fortune's “100 Best Companies to Work for" List?. Business \& Society 45(2), pp. 235-248.

Boone, A. L., Field, L. C., Karpoff, J. M., Raheja, C. G. (2007). The Determinants of Corporate Board Size and Composition: An Empirical Analysis. Journal of Financial Economics 85(1), pp. 66-101.

Brammer, S., Millington, A., Pavelin, S. (2009). Corporate Reputation and Women on the Board. British Journal of Management 20, pp. 17-29.

Burgess, Z., Tharenous, P. (2002). Women Board Directors: Characteristics of the Few. Journal of Business Ethics 37, pp. 39-49.

Campbell, K., Vera, A. M. (2010). Female Board Appointments and Firm Valuation: Short and Long-term Effects. Journal of Management \& Governance 14(1), pp. 37-59.

Carter, D. A., Simkins, B. J., Simpson, W. G. (2003). Corporate Governance, Board Diversity, and Firm Value. Financial Review 38(1), pp. 33-53.

Carter, D. A., D'Souza, F., Simkins, B. J., Simpson, W. G. (2010). The Gender and Ethnic Diversity of US Boards and Board Committees and Firm Financial Performance. Corporate Governance: An International Review 18(5), pp. 396-414.

Coles, J. L., Daniel, N. D., Naveen, L. (2014). Board advising. Working Paper (Abstract available at: http://ssrn.com/abstract=2002250).

Conyon, M. J., Mallin, C. (1997). Women in the Boardroom: Evidence from Large UK Companies. Corporate Governance: An International Review 5(3), pp. 112-117.

Core, J. E., Holthausen, R. W., Larcker, D. F. (1999). Corporate Governance, Chief Executive Officer Compensation, and Firm Performance. Journal of Financial Economics 51(3), pp. 371-406.

Cornelli, F., Karakas, O. (2012). Corporate Governance of LBOs: The Role of Board. Working Paper, (Abstract available at: http://ssrn.com/abstract=1875649).

Cyert, R. M., Kang, S., Kumaar, P. (2002). Corporate Governance, Takeovers, and Top-Management Compensation: Theory and Evidence. Management Science 48(4), pp. 453-469.

Dalton, D. R., Dalton, C. M. (2010). Women and Corporate Boards of Directors: The Promise of Increased, and Substantive, Participation in the Post Sarbanes-Oxley Era. Business Horizons 53(3), pp. 257-268.

Daniel, N. D., McConnel, J. J., Naveen, L. (2013). The Advisory Role of Foreign Directors in U.S. Firms. Working paper (Abstract available at: http://ssrn.com/abstract=2023420).

Dobbin, F., Jung, J. (2011). Corporate Board Gender Diversity and Stock Performance: The Competence Gap or Institutional Investor Bias. North Carolina Law Review 89, pp. 809-838.

Dunn, P. (2012). Breaking the Boardroom Gender Barrier: The Human Capital of Female Corporate Directors. Journal of Management \& Governance 16, pp. 557-570.

Erhardt, N. L., Werbel , J. D., Shrader, C. B. (2003). Board of Director Diversity and Firm Financial Performance. Corporate Governance: An International Review 11(2), pp. 102-111.

Ferreira, D. (2010). Board Diversity. Chapter 12 in Corporate Governance: A Synthesis of Theory, Research, and Practice. Anderson, R. and H.K. Baker (eds.), John Wiley \& Sons, pp. 225-242.

Fich, E. M., Shivdasani, A. (2006). Are Busy Boards Effective Monitors?. Journal of Finance 61(2), pp. 689-724.

Francoeur, C., Labelle, R., Sinclair-Desgagne, B. (2008). Gender Diversity in Corporate Governance and Top Management. Journal of Business Ethics 81, pp. 83-95. 
Gertner, R., Kaplan, S. N. (1996). The Value-Maximizing Board. Working Paper (Abstract available at: http://ssrn.com/abstract=10975).

Gibbons, R., Murphy, K. J. (1992). Optimal Incentive Contracts in the Presence of Career Concerns: Theory and Evidence. Journal of Political Economy 100(3), pp. 468-505.

Graham, J. R., Harvey, C. (2001). The Theory and Practice of Corporate Finance: Evidence from the Field. Journal of Financial Economics 60, pp. 187-243.

Greve, P., Nielsen, S., Ruigrok, W. (2009). Transcending Borders with International Top Management Teams: A Study of European Financial Multinational Corporations. European Management Journal 27, pp. 213-224.

Heijltjes, M., Olie, R., Glunk, U. (2003). Internationalization of Top Management Teams in Europe. European Management Journal 21(1), pp. 89-97.

Karayel, M., Dogan, M. (2014). Relationship between Board Gender Diversity and Financial Performance: A Study on BIST 100 Companies. Suleyman Demirel University The Journal of Faculty of Economics and Administrative Sciences 19(2), pp. 75-88.

Karen, L., Thompson, D. E. (1997). Above the Glass Ceiling?: A Comparison of Matched Samples of Female and Male Executives. Journal of Applied Psychology 82(3), pp. 359-375.

Korniotis, G. M., Kumar, A. (2011). Do Older Investors Make Better Investment Decisions?. Review of Economics and Statistics 91(1), pp. 244-265.

Lückerath-Rovers, M. (2013). Women on Boards and Firm Performance. Journal of Management \& Governance 17(2), pp. 491-509.

Masulis, R. W., Wang, C., Xie, F. (2012). Globalizing the Boardroom - The Effects of Foreign Directors on Corporate Governance and Firm Performance. Journal of Accounting and Economics 53, pp. 527-554.

McIntyre, M. L., Murphy, S. A., Mitchell, P. (2009). The Top Team: Examining Board Composition and Firm Performance. Corporate Governance 7(5), pp. 547-561.

Morikawa, M. (2014). What Type of Companies Have Female and Foreign Directors?. Working Paper (Abstract available at: http://ssrn.com/abstract=2466787).

Ntim, C. G. (2014). Board Diversity and Organizational Valuation. Journal of Management \& Governance (in press).

Ocak, M. (2013). Yönetim Kurulu ve Üst Yönetimde Yer Alan Kadınların Finansal Performansa Etkisi: Türkiye'ye İlişkin Bulgular. The Journal of Accounting and Finance Dergisi 60, pp. 107-126.

Oxelheim, L., Randoy, T. (2003). The Impact of Board Membership on Firm Value. Journal of Banking \& Finance 27, pp. 2369-2392.

Peni, E. (2014). CEO and Chairperson Characteristics and Firm Performance. Journal of Management \& Governance 18(1), pp. 185-2005.

Peterson, C. A., Philpot, J. (2007). Women's Role on US Fortune 500 Boards: Director Expertise and Committee Memberships. Journal of Business Ethics 72, pp. 177-196.

Piekkari, R., Oxelheim, L., Randoy, T. (2013). The Role of Language in Corporate Governance: The Case of Board Internationalization. Working Paper (Abstract available at: http://ssrn.com/abstract=2323616).

Ramaswamy, K., Li, M. (2001). Foreign Investors, Foreign Directors and Corporate Diversification: An Empirical Examination of Large Manufacturing Companies in India. Asia Pacific Journal of India 18, pp. 207-222.

Rose, C. (2007). Does Female Board Representation Influence Firm Performance? The Danish Evidenc. Corporate Governance: An International Review 15(2), pp. 404-413.

Ruigrok, W., Peck, S., Tacheva, S. (2007). Nationality and Gender Diversity on Swiss Corporate Boards. Corporate Governance: An International Review 15(4), pp. 546-557.

Sealy, R. H. V., Singh, V. (2010). The Importance of Role Models and Demographic Context for Senior Women's Work Identity Development. International Journal of Management Reviews 12(3), pp. 284-300. 
Shin, T. (2012). The Gender Gap in Executive Compensation: The Role of Female Directors and Chief Executive Officers. The ANNALS of the American Academy of Political and Social Science 639(1), pp. 258-278.

Singh, V., Terjesen, S., Vinnicombe, S. (2008). Newly Appointed Directors in the Boardroom: How Do Women and Men Differ?. European Management Journal 26(1), pp. 48-58.

Solakoglu, M. N. (2013). The Role of Gender Diversity on Firm Performance: A Regression Quantile Approach. Applied Economics Letters 20(17), pp. 1562-1566.

Tate, G., Yang, L. (2014). Female Leadership and Gender Equity: Evidence from Plant Closure. Journal of Financial Economics (in press).

Terjesen, S., Sealy, R., Singh, V. (2009). Women Directors on Corporate Boards: A Review and Research Agenda. Corporate Governance: An International Review 17(3), pp. 320-337.

Van Veen, K., Marsman, I. (2008). How International are Executive Boards of European MNCs? Nationality Diversity in 15 European Countries. European Management Journal 26, pp. 188-198.

Virtanen, A. (2012). Women on Boards of Listed Companies: Evidence from Finland. Journal of Management \& Governance 16(4), pp. 571-593.

Waelchli, U., Zeller, J. (2013). Old Captains at the Helm: Chairman Age and Performance. Journal of Banking \& Finance 37(5), pp. 1612-1628.

Wegge, J., Roth, C., Neubach, B., Schmidt, K., Kanfer, R. (2008). Age and Gender Diversity as Determinants of Performance and Health in a Public Organization: The Role of Task Complexity and Group Size. Journal of Applied Psychology 93(6), pp. 1301-1313. 